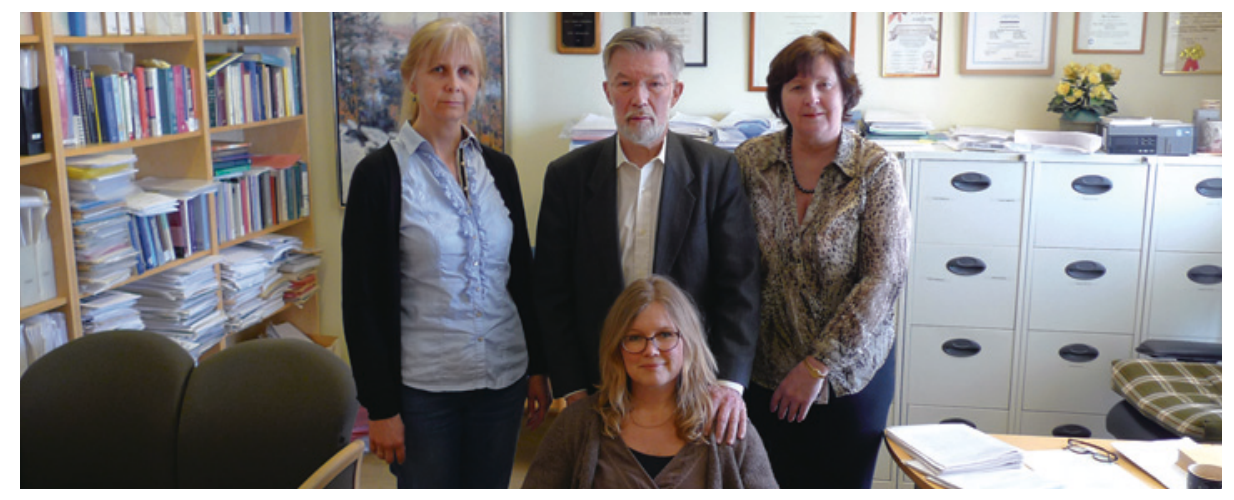

Studiens førsteforfatter Hanne-Sofie Johnsen Dahl (sittende), bak fra venstre Randi Ulberg, Per Høglend (prosjektleder) og Anne Grethe Hersoug. Foto: Martin Fronth Furan

\title{
Psykoterapeutens følelser påvirker behandlingsresultatene
}

En velvillig foreldreholdning hos terapeuten gir positive langtidseffekter hos pasienter med alvorlig personlighetspatologi.

Overføring og motoverføring er sentrale begreper i psykoanalytisk orientert psykoterapi. Vi bringer alle med oss noe i møtet med andre (overføring), og vi reagerer på den andre (motoverføring). Overførings- og motoverføringsfenomener eksisterer i alle relasjoner og alle typer psykoterapi. Det har til nå vært publisert få studier som undersøker motoverføringen i individuell psykoterapi. Kan terapeutens indre opplevelser under konsultasjonene ha betydning for terapiresultatene over lang tid? Dette er nylig undersøkt av forskere i den norske FEST-studien (1).

I studien ble 100 pasienter randomisert til ett års dynamisk psykoterapi med og uten overføringstolkninger. Deltakerne ble fulgt $i$ tre år etter avsluttet terapi med en rekke evalueringer. Etter hver psykoterapitime fylte terapeutene ut en liste med følelsesord, og graderte styrken av disse følelsene. Terapeuters motoverføring kan ofte minne om en velvillig foreldreholdning, det som kalles parental motoverføring, bestående av ordene «ømhet for, moderlig, dominerende og viktig». Denne studien undersøkte sammenhengene mellom en terapeutvariabel (parental motoverføring), en pasientvariabel (personlighetspatologi) og en teknikkvariabel (overføringstolkninger). Langtidseffektene av overføringstolkninger varierte både med grad av motoverføring og grad av personlighetspatologi - en treveisinteraksjon. Når parental motoverføring økte, ble effekten av overføringstolkninger særlig positiv for pasienter med alvorlig personlighetspatologi, men negativ for pasienter uten personlighetsforstyrrelser.

- En måte å forstå disse funnene på, er at en foreldreliknende holdning hos terapeuten er en kilde til støtte, veiledning og forståelse som pasienter med alvorlig personlighetspatologi har manglet, sier pro- fessor og prosjektleder Per Høglend ved Institutt for psykiatri, Seksjon Vinderen, Universitetet i Oslo. - Pasienter uten personlighetsforstyrrelser kan oppleve en slik terapeutholdning som påtrengende, unødvendig og infantiliserende.

- Det er overraskende at parental motoverføring har så sterk påvirkningskraft så lang tid etter terapiavslutning. Studien indikerer at terapeuter bør ta i betraktning ikke bare pasientens symptomer og personlighetspatologi, men også egne følelser og reaksjoner i møte med pasienten. Det er en daglig utfordring for psykoterapeuter - og leger å identifisere behovene til den enkelte pasient. Ved å studere følelsesmønstre som gjentar seg over tid i en terapi, kan aspekter ved motoverføring som i utgangspunktet er ubevisste, bli klarere, sier Høglend.

\section{Studier om overføring}

FEST-studien (First Experimental Study of Transference-interpretation) er en randomisert klinisk studie med «dismantling design», spesielt utformet for å måle langtidseffektene av overføringstolkninger, og hvem som har nytte av slike tolkninger. Studien har siden 2006 gitt opphav til rundt 30 vitenskapelige publikasjoner. Forskningen utgår fra Enhet for voksenpsykiatri, Universitetet i Oslo. Forskergruppen er uavhengig og består av sju psykiatere og tre psykologer knyttet til psykiatriske poliklinikker og spesialistpraksiser i Oslo-området.

\section{Hanne Støre Valeur}

Tidsskriftet

\section{Litteratur}

1. Dahl H-S, Røssberg Jl, Crits-Christoph P et al. Long-term effects of analysis of the patient-therapist relationship in the context of patients' personality pathology and therapists' parental feelings. J Consult Clin Psychol 2014; 82: 460-71.
Ordforklaringer

Overføring og overføringstolkninger: Uttrykk lansert av Sigmund Freud (1856-1939). Terapeut-pasient-forholdet er farget av pasientens tidligere eller nåværende relasjoner og følelsesmessige erfaringer. Analyse av innholdet i overføringen er den sentrale teknikken i psykodynamisk psykoterapi. Terapeuten utforsker og tolker pasient-terapeut-interaksjonen i samarbeid med pasienten. Overføringstolkninger kan gi en sterk emosjonell opplevelse og belyse viktige sider av pasientens problemer i mellommenneskelige relasjoner.

Motoverføring: De følelser og reaksjoner som vekkes hos terapeuten i møtet med pasienten. Tidligere ble motoverføring tolket som et uttrykk for terapeutens ubevisste og «blinde flekker». I dagens psykodynamiske terapi sees motoverføring som totaliteten av terapeutens følelser, holdninger og reaksjoner. I likhet med overføringen kan motoverføringen være en kilde til forståelse av pasientens problemer, særlig de som oppstår i nære relasjoner. 